\title{
BIOACCUMULATION OF ${ }^{137}$ Cs AND ${ }^{60}$ Co IN FRESHWATER PLANTS
}

\author{
MIROSLAV HORNÍK, MARTIN PIPÍŠKA, JOZEF AUGUSTÍN \\ Department of Biotechnology, University of SS. Cyril and Methodius, J. Herdu 2, \\ Trnava, SK-917 01, Slovak Republic (hornikm@ucm.sk)
}

\begin{abstract}
Contamination of the aquatic environment by the heavy metals and radionuclides has become a serious concern in the world. In our study, gamma-spectrometry of freshwater plants Bacopa monnieri and Egeria densa growing in cultivation media spiked with ${ }^{137} \mathrm{CsCl}$ and ${ }^{60} \mathrm{CoCl}_{2}$ was used for quantitative determination of bioaccumulation kinetic and distribution $\mathrm{Cs}^{+}$and $\mathrm{Co}^{2+}$ ions in plant tissues. We found, that bioaccumulation of $\mathrm{Cs}$ and Co by fully immersed B. monnieri in Hoagland media (HM) was dependent on ion concentration in medium. Approx. 5-times lower Cs uptake $2.9 \mathrm{nmol} / \mathrm{g}$ (d.w.) was obtained in plants cultivated in $20 \%$ HM than from deionized water. The maximal Co uptake was 4-times higher than cesium uptake at the same conditions. Both $\mathrm{Cs}$ and $\mathrm{Co}$ were localized mainly in roots. The highest immobilization from roots to shoots was found in the case of Co uptake from deionized water with concentration ratio $[\mathrm{Co}]_{\text {leaves }}:[\mathrm{Co}]_{\mathrm{stem}}:[\mathrm{Co}]_{\mathrm{root}}=1.00: 5.33: 56.8$. Cesium uptake by submerged plant $E$. densa was also strongly dependent on nutrients concentration in medium. However, in the case of cobalt uptake this dependence was less pronounced. Nutrients concentration also had a significant influence on distribution of Cs between stems and leaves of E. densa. Cesium was localized in leaves, however with increasing of nutrients concentration in cultivation media Cs was localized for account of stem. On the other hand, cobalt was immobilized mainly in leaves in whole range of nutrients concentration. Obtained data can serve as a models for understanding of phytoaccumulation of radionuclides from open water ponds and water channels in the vicinity of nuclear power plants and monovalent and bivalent metals from industrial sources of contamination.
\end{abstract}

Keywords: cesium, cobalt, ${ }^{137} \mathrm{Cs},{ }^{60} \mathrm{Co}$, bioaccumulation, freshwater plants

\section{Introduction}

Heavy metals are toxic pollutants released into the surface and ground water as a result of different activities such as industries, mining, and agriculture. At present, a number of technologies can be used to remove of heavy metals from contaminated water such as filtration, reverse osmosis, solvent extraction, adsorption, chemical precipitation and ion-exchange (CHEREMISINOFF, 2002). However, these methods are not efficient in removing low heavy metals concentrations, can be relatively expensive and may fail to achieve legal limits.

Contrary to this, phytoremediation, i.e. removal of pollutants by the use of plants offers a promising technology for heavy metal removal from waste water (STERNBERG, 2007; FIOL et al., 2005). Aquatic macrophytes have a great potential to accumulate heavy metals inside their plant body (PRASAD, 2007; OTTE and JACOB, 2006). Most studies on pollutant bioaccumulation in macrophytes are aimed at assessing removal efficiency or toxic effects without taking into account the metal bioaccumulation process by macrophytes, key knowledge not only to understand the behavior of macrophytes but also to optimize effluent depuration by means of artificial wetlands. Wetlands have significant merits of low capital 
and operating costs compare with conventional system as activated sludge, aerated lagoon system etc.. This technology has been used mainly in the case of mine waters (see e.g. LESLEY et al., 2008; LESLEY and YOUNGER, 2007; BATTY et al., 2005).

The nuclear revolution (weapons testing or accidents at power production) has resulted in the large-scale release of cesium into the environment, in particular ${ }^{134} \mathrm{Cs}(\tau=2.07 \mathrm{y})$ and the long-lived radionuclide ${ }^{137} \mathrm{Cs}(\tau=30.2 \mathrm{y})$. Radiocesium ${ }^{137} \mathrm{Cs}$ persists in aquatic systems, with environmental half-lives in monomitic lakes, meromitic lakes and flowing rivers 1.2, 6.7 and 1.4 years, respectively (AVERY, 1996). Its almost unlimited solubility in aquatic systems and chemical similarity to potassium means that it can be easily assimilated by terrestrial and aquatic organisms (MOULD, 2000; KERPEN, 1986). Large variations in the activity concentrations of ${ }^{137} \mathrm{Cs}$ from Chernobyl nuclear accident in fish and lake water were still being observed in the 1990s and even in the 2000s (SAXÉN and ILUS, 2008; SAXÉN, 2007).

Cobalt usually occurs in the environment in association with other metals such as copper, nickel, manganese and arsenic. Cobalt released by human activities comes mainly from: nickel, copper, silver, lead and iron mines and refineries; metal production facilities; industrial boilers that burn coal and oil; vehicles that burn gasoline; and incinerators that burn refuse and sewage sludge (PEREZ-ESPINOZA et al., 2005). Cobalt, as microelement for methanogenic bacteria, not for higher plants, can be also trapped in anaerobic bottom sediments. Cobalt ${ }^{60} \mathrm{Co}(\tau=5.27 \mathrm{y})$ is also present in low-level radioactive wastes (CARON and MANKARIOS, 2004).

Our previous papers were oriented to bioaccumulation of radionuclides by terrestrial vascular plants from defined water solutions (HORNÍK et al., 2007; BARÁTOVÁ et al., 2006). The objectives of this study are the investigation of ${ }^{137} \mathrm{Cs}$ and ${ }^{60} \mathrm{Co}$ uptake and their distribution in roots, stems and leaves of freshwater plants Bacopa monnieri and Egeria densa, in order to evaluate the role of nutrient concentration in bioaccumulation processes. B. monnieri is an emergent, wetland macrophyte. It grows very fast with its creeping stem in wetlands as a weed. It is well known from ancient times for its medicinal properties having active ingredients like bacosides and bacopasides. E. densa is an introduced invasive species, mainly via the aquarium trade. Also, this invasive submerged species is distributed in lakes and rivers of Europe.

\section{Materials and methods}

\subsection{Plant material}

Freshwater plants Bacopa monnieri and Egeria densa were obtained from common aquarium shops. One week before experimentation, plants were pre-cultivated in $15 \mathrm{dm}^{3}$ aquaria filled with 50\% Hoagland medium (HM), (HOAGLAND, 1920) at artificial illumination with $12 \mathrm{~h} / 12 \mathrm{~h} \mathrm{light/dark}$ cycle (illumination with 2 tubes Brilliant daylight - $6000 \mathrm{~K}, 1300 \mathrm{~lm}$ and Tropic sun $-4700 \mathrm{~K}, 1000 \mathrm{~lm}$; Sera, D) and at $22 \pm 2^{\circ} \mathrm{C}$. For experiments, healthy green plants of comparable weight $(0.4-0.5 \mathrm{~g}$ 
fresh weight; f.w.) were used and three-times washed in deionized water before experiments.

The following molar concentrations of salts were presented in full-strength $\mathrm{HM}$ $(\mathrm{mM}): \mathrm{MgSO}_{4} .7 \mathrm{H}_{2} \mathrm{O}-1.5 ; \mathrm{KNO}_{3}-4.0 ; \mathrm{CaCl}_{2}-4.0 ; \mathrm{NaH}_{2} \mathrm{PO}_{4} \cdot 2 \mathrm{H}_{2} \mathrm{O}$ - 1.87; $\mathrm{Na}_{2} \mathrm{HPO}_{4} .12 \mathrm{H}_{2} \mathrm{O}-0.13 ; \mathrm{FeSO}_{4} .7 \mathrm{H}_{2} \mathrm{O}-0.06 ; \mathrm{NaNO}_{3}-4.0 ; \mathrm{NH}_{4} \mathrm{Cl}-3.17 ; \mathrm{NH}_{4} \mathrm{NO}_{3}-$ $2.0 ; \mathrm{H}_{3} \mathrm{BO}_{3}-0.14 ; \mathrm{Na}_{2} \mathrm{MoO}_{4} .2 \mathrm{H}_{2} \mathrm{O}-0.0025 ; \mathrm{MnSO}_{4} .5 \mathrm{H}_{2} \mathrm{O}-0.21 ; \mathrm{ZnSO}_{4} .7 \mathrm{H}_{2} \mathrm{O}-$ $0.023 ; \mathrm{CuSO}_{4} .5 \mathrm{H}_{2} \mathrm{O}-0.033 ; \mathrm{pH} 6.5$.

\subsection{Bioaccumulation experiments}

For bioaccumulation experiments, freshwater plants B. monnieri or E. densa (0.4$0.5 \mathrm{~g}$; f.w.) were placed on the bottom in $100 \mathrm{~cm}^{3}$ Erlenmayer flasks containing $50 \mathrm{~cm}^{3}$ deionized water or HM diluted with deionized water in the ratio 1:1, 1:3, 1:4, 1:7, 1:11 or 1:25, and spiked with both ${ }^{137} \mathrm{CsCl}$ and ${ }^{60} \mathrm{CoCl}_{2}$. Cultivation was carried out at artificial illumination with $12 \mathrm{~h} / 12 \mathrm{~h}$ light/dark cycle $(2000 \mathrm{~lx})$ and $22 \pm 2{ }^{\circ} \mathrm{C}$ under occasional shaking. In time intervals, aliquots were taken and the remaining radioactivity in the cultivation media was estimated. At the end of the experiments, plants were washed in deionized water, dried at $60^{\circ} \mathrm{C}$ during $48 \mathrm{~h}$ and incorporated radioactivity of ${ }^{137} \mathrm{Cs}$ or ${ }^{60} \mathrm{Co}$ in leaves, stems or roots was measured by gammaspectrometry. All the experiments were performed in triplicate series.

\subsection{Radiometric analysis}

For radiometric determination ${ }^{137} \mathrm{Cs}$ and ${ }^{60} \mathrm{Co}$ in plants and cultivation media gamma-spectrometric scintillation detector 54BP54/2-X with well type crystal NaI(Tl) (Scionix, NL) with data processing software Scintivision32 (ORTEC, USA) were used. Counting time $600 \mathrm{~s}$ allowed obtaining data with measurement error $<2 \%$, which do not reflect other source of errors. Standardized solutions of ${ }^{137} \mathrm{CsCl}(5.723$ $\left.\mathrm{MBq} / \mathrm{cm}^{3} ; 20 \mathrm{mg} / \mathrm{dm}^{3} \mathrm{CsCl}+3 \mathrm{~g} / \mathrm{dm}^{3} \mathrm{HCl}\right)$ and ${ }^{60} \mathrm{CoCl}_{2}\left(5.571 \mathrm{MBq} / \mathrm{cm}^{3} ; 20 \mathrm{mg} / \mathrm{dm}^{3}\right.$ $\mathrm{CoCl}_{2}+3 \mathrm{~g} / \mathrm{dm}^{3} \mathrm{HCl}$ ) were obtained from Czech metrology institute (CZ).

\subsection{Speciation modeling}

Prediction of $\mathrm{Cs}$ and $\mathrm{Co}$ speciation in the nutrient solutions as a function of the total salt concentrations, solution $\mathrm{pH}$ and temperature was performed using the software Visual MINTEQ ver. 2.53. This speciation model allows the calculation of the composition of solution, in regard to formation of metal complexes.

\section{Results and discussion}

Freshwater plants may take up nutrients from the sediments by roots or may absorb nutrients from the water column by foliar uptake. Determining the principal mode of toxic metals and radionuclides uptake by macrophytes is important because it affects the interpretation of the role of macrophytes in aquatic systems. If root 
uptake is the principal mode, then the metals and radionuclides content of the macrophytes represents remobilization from the sediments. If foliar uptake is the principal mode, then the metals and radionuclides content of the macrophytes represents a reduction in the water column concentration with the macrophytes serving as at least a temporary sink for these pollutants (KELLY and PINDER III, 1996). However, in these processes the speciation of metals and radionuclides in both water and sediment can play an important role. For example, MADRUGA and CARREIRO (1992) found in Tejo River water, that ${ }^{60} \mathrm{Co}$ was almost $100 \%$ in cationic forms, however, in the presence of sediment there was a decrease in proportion of cationic forms (to $50 \%$ ), with some anionic forms appearing.
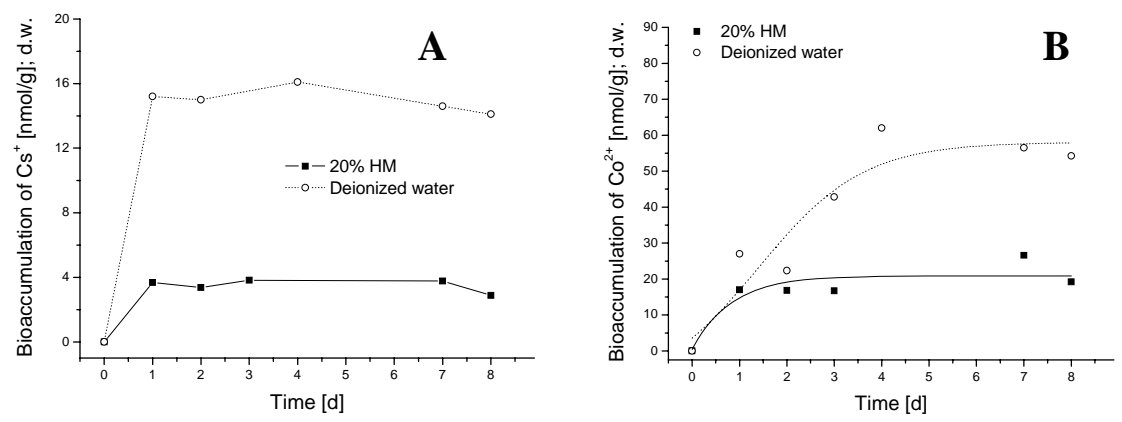

Fig. 1. Bioaccumulation kinetics of $\mathrm{Cs}^{+}$ions $(\mathrm{A})$ and $\mathrm{Co}^{2+}(\mathrm{B})$ by freshwater plant B. monnieri $\left(25 \mathrm{~g} / \mathrm{dm}^{3}\right.$; f.w.). Fully immersed plants were cultivated in deionized water or $20 \%$ Hoagland medium (HM), $\mathrm{pH} 6.5$ containing $0.12 \mu \mathrm{mol} / \mathrm{dm}^{3} \mathrm{CsCl}\left(17 \mathrm{kBq} / \mathrm{dm}^{3}{ }^{137} \mathrm{CsCl}\right)$ and $0.11 \mu \mathrm{mol} / \mathrm{dm}^{3} \mathrm{CoCl}_{2}\left(13 \mathrm{kBq} / \mathrm{dm}^{3}{ }^{60} \mathrm{CoCl}_{2}\right)$ at light/dark cycle $12 \mathrm{~h} / 12 \mathrm{~h}(2000 \mathrm{~lx})$ and at $22 \pm 2^{\circ} \mathrm{C}$. Total uptake of Cs: deionized water $-8.3 \% ; 20 \% \mathrm{HM}$ $-0.9 \%$. Total uptake of Co: deionized water $-35 \% ; 20 \% \mathrm{HM}-6.3 \%$. Data represent average of three independent experiments.

Bioaccumulation kinetics of $\mathrm{Cs}^{+}$and $\mathrm{Co}^{2+}$ ions by emergent freshwater plant Bacopa monnieri are presented in Fig. 1A, B. Under given experimental condition, i.e. the initial concentration $\mathrm{C}_{0}=0.12 \mu \mathrm{mol} / \mathrm{dm}^{3} \mathrm{CsCl}$ and biomass concentration $25 \mathrm{~g} / \mathrm{dm}^{3}$ (f.w.) at $22^{\circ} \mathrm{C}$ the maximum cesium uptake was observed after $24 \mathrm{~h}$ and was stable within the next 7 days. As can be seen from Fig. 1A, bioaccumulation of Cs is dependent on ion concentration in medium. Cesium uptake $14.1 \mathrm{nmol} / \mathrm{g}$ (dry weight; d.w.) was obtained in deionized water after 8 days cultivation. Approximately 5-times lower $2.9 \mathrm{nmol} / \mathrm{g}$ (d.w.) was found at plants cultivation in $20 \% \mathrm{HM}$, where concentration of competing $\mathrm{K}^{+}$and $\mathrm{NH}_{4}{ }^{+}$ions was 0.8 and $1.2 \mathrm{mmol} / \mathrm{dm}^{3}$, respectively. Nevertheless, as can be calculated by Visual MINTEQ speciation program, cesium in $20 \% \mathrm{HM}$ at $\mathrm{pH} 6.5$ occurs practically as free cation $\left(>99 \% \mathrm{Cs}^{+}\right)$.

Monovalent $\mathrm{K}^{+}$and $\mathrm{NH}_{4}^{+}$ions act competitively on cesium uptake by plants. Vascular plants can accumulate $\mathrm{Cs}^{+}$ions through both their leaves and through their roots. Substrate affinity i.e. $\mathrm{K}_{\mathrm{m}}$ values for $\mathrm{Cs}^{+}$uptake in shoots and roots of winter wheat is 25.5 and $16.7 \mu \mathrm{mol} / \mathrm{dm}^{3}$ respectively. According to SHAW et al. (1992) the measured transfer factor of roots is one order of magnitude greater than that of shoots. SMITH et al. (2003) in a whole-lake experiment at study to reduce the bioaccumulation of radiocesium ${ }^{137} \mathrm{Cs}$ in fish in lakes contaminated 
by the Chernobyl accident found, that after the addition of $15 \mathrm{t}$ of potassium chloride to Lake Svyatoe, Kostiukovichy resulted in a decrease in activity concentration of ${ }^{137} \mathrm{Cs}$ to approximately $40 \%$ of pre-countermeasure values in a number of different fish species. However, the addition of $4 \mathrm{~kg}{ }^{133} \mathrm{CsCl}$ into an 11.4-ha, $157000 \mathrm{~m}^{3}$ reservoir previously contaminated with ${ }^{137} \mathrm{Cs}$ from past reactor operations at the US Department of Energy's Savannah River Site near Aiken, South Carolina (USA) increased of $6.1 \mathrm{MBq}$ of ${ }^{137} \mathrm{Cs}\left(1.9 \mathrm{mg}{ }^{137} \mathrm{Cs}\right)$ in the water column (PINDER III et al., 2006; 2005). These authors supposed, that possible sources for the increased ${ }^{137} \mathrm{Cs}$ included release from the sediments (the principal source), release from the approx. $26000 \mathrm{~kg}$ of aquatic macrophytes that occupied $80 \%$ of the reservoir, and wash-in from the pond's watershed.
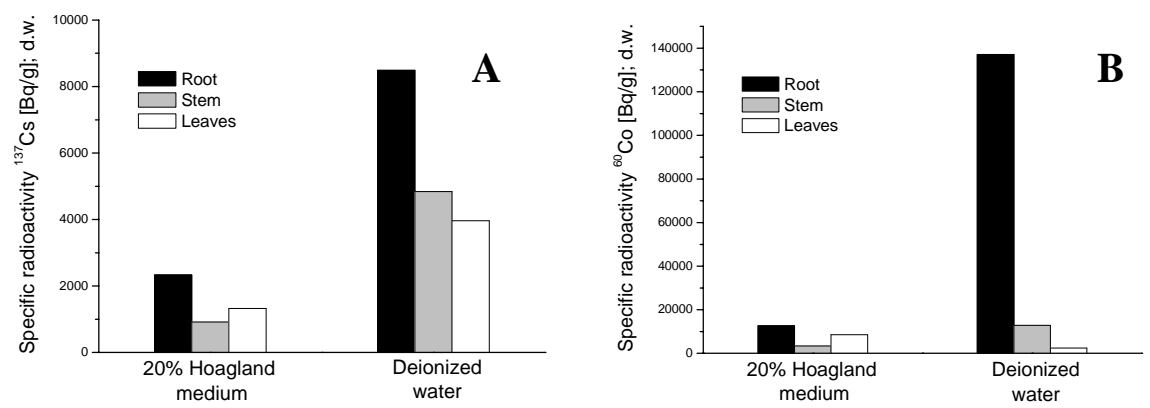

Fig. 2. Specific radioactivities of ${ }^{137} \mathrm{Cs}(\mathrm{A})$ and ${ }^{60} \mathrm{Co}(\mathrm{B})$ in root, stem and leaves of B. monnieri after 8 days cultivation of fully immersed plants in deionized water or $20 \% \mathrm{HM}, \mathrm{pH} 6.5$ containing $0.12 \mu \mathrm{mol} / \mathrm{dm}^{3} \mathrm{CsCl}$ $\left(17 \mathrm{kBq} / \mathrm{dm}^{3}{ }^{137} \mathrm{CsCl}\right)$ and $0.11 \mu \mathrm{mol} / \mathrm{dm}^{3} \mathrm{CoCl}_{2}\left(13 \mathrm{kBq} / \mathrm{dm}^{3}{ }^{60} \mathrm{CoCl}_{2}\right)$ at light/dark cycle $12 \mathrm{~h} / 12 \mathrm{~h}(2000 \mathrm{~lx})$ and at $22 \pm 2{ }^{\circ} \mathrm{C}$. Data represent average of three independent experiments.

Bioaccumulation kinetic of $\mathrm{Co}^{2+}$ ions by B. monnieri was identical with the process of $\mathrm{Cs}$ bioaccumulation at the same conditions, but only in the case of plants cultivation in $20 \% \mathrm{HM}$ (Fig. 1B). Cobalt in $20 \% \mathrm{HM}$ at pH 6.5 occurs practically as free cation $\left(>93 \% \mathrm{Co}^{2+}\right)$. When plants were cultivated in deionized water containing $0.11 \mu \mathrm{mol} / \mathrm{dm}^{3} \quad \mathrm{CoCl}_{2}$, the bioaccumulation of cobalt gradually increased to the maximum $62 \mathrm{nmol} / \mathrm{g}$ (d.w.) in 5 day of cultivation, and then slowly decreased to the value $54 \mathrm{nmol} / \mathrm{g}$ (d.w.) in 8 day of plants cultivation. The bioaccumulation of Co is also dependent on ion concentration in medium. It can be concluded, that cobalt was accumulated in more extent than cesium practically at the same conditions. ADAM and GARNIER-LAPLACE (2003) found similar results at accumulation of ${ }^{137} \mathrm{Cs}$ and ${ }^{60} \mathrm{Co}$ by freshwater alga Cyclotella meneghiana.

From results of cesium distribution in plant organs of $B$. monnieri we found (Fig. 2A), that cesium is mainly localized in roots than in stems and leaves with concentration ratio $[\mathrm{Cs}]_{\text {leaves }}:[\mathrm{Cs}]_{\text {stem }}:[\mathrm{Cs}]_{\text {root }}=1.00: 0.69: 1.76$ at plants cultivation in $20 \% \mathrm{HM}$ and $[\mathrm{Cs}]_{\text {leaves }}:[\mathrm{Cs}]_{\text {stem }}:[\mathrm{Cs}]_{\text {root }}=1.00: 1.22: 2.14$ at plants cultivation in deionized water. Similarly, cobalt was mainly immobilized in roots with concentration ratio $[\mathrm{Co}]_{\text {leaves }}:[\mathrm{Co}]_{\text {stem }}:[\mathrm{Co}]_{\mathrm{root}}=1.00: 0.39: 1.49$ at plants cultivation in $20 \% \mathrm{HM}$ (Fig. 2B). In the case of plants cultivation in deionized water 
cobalt was much more immobilized in roots with concentration ratio $[\mathrm{Co}]_{\text {leaves }}$ $:[\mathrm{Co}]_{\text {stem }}:[\mathrm{Co}]_{\text {root }}=1.00: 5.33: 56.8$. Its generally known, that at emergent species of water plants root uptake is presumed to be the dominant mechanism of nutrients absorption. In this regard, mineral nutrients, mainly macroelements ( $\mathrm{Ca}$ and $\mathrm{Mg}$ ), from $20 \% \mathrm{HM}$ are probably preferentially accumulated by roots than cobalt.
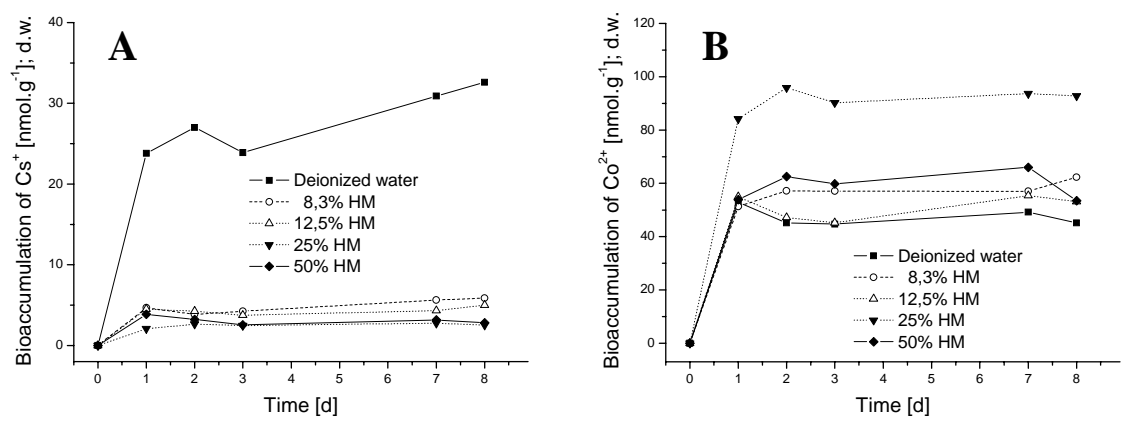

Fig. 3. Bioaccumulation kinetics of $\mathrm{Cs}^{+}(\mathrm{A})$ and $\mathrm{Co}^{2+}$ (B) ions by E. densa $\left(20 \mathrm{~g} / \mathrm{dm}^{3}\right.$; f.w.). Fully immersed plants were cultivated in deionized water or diluted $\mathrm{HM}(8.3 \%, 12.5,25 \%$ or $50 \%)$, pH 6.5 containing $0.12 \mu \mathrm{mol} / \mathrm{dm}^{3} \mathrm{CsCl}\left(17 \mathrm{kBq} / \mathrm{dm}^{3}{ }^{137} \mathrm{CsCl}\right)$ and $0.11 \mu \mathrm{mol} / \mathrm{dm}^{3} \mathrm{CoCl}_{2}\left(13 \mathrm{kBq} / \mathrm{dm}^{3}{ }^{60} \mathrm{CoCl}_{2}\right)$ at light $/$ dark cycle $12 \mathrm{~h} / 12 \mathrm{~h}(2000 \mathrm{~lx})$ and $22 \pm 2^{\circ} \mathrm{C}$. Total Cs uptake $(\%)$ : deionized water $-46.4 ; 8.3 \% \mathrm{HM}-5.7 ; 12.5 \%$ $\mathrm{HM}-6.4 ; 25 \% \mathrm{HM}-2.1 ; 50 \% \mathrm{HM}-3.3$. Total Co uptake $(\%)$ : deionized water $-70.3 ; 8.3 \% \mathrm{HM}-66.8$; $12.5 \% \mathrm{HM}-72.0 ; 25 \% \mathrm{HM}-81.8 ; 50 \% \mathrm{HM}-70.6$. Data represent average of three independent experiments.
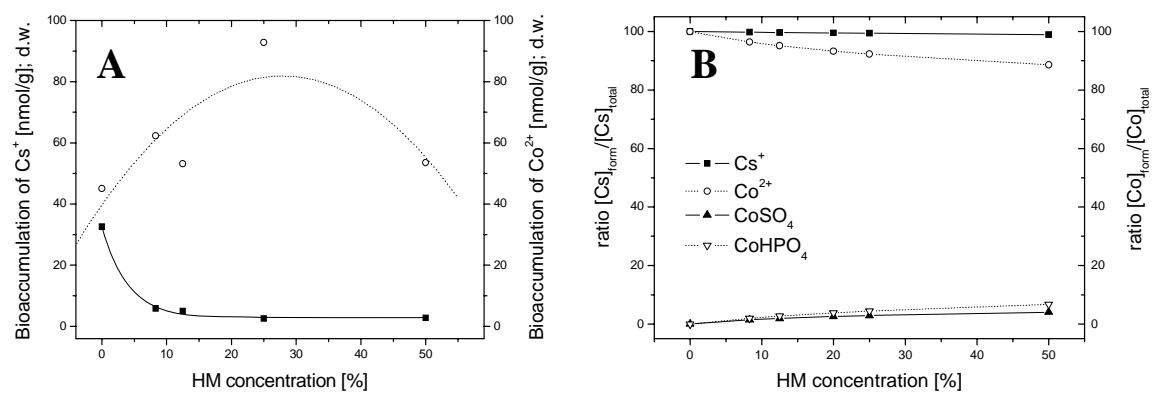

Fig. 4. A. Dependence of bioaccumulation of $\mathrm{Cs}^{+}(-\mathbf{m}-)$ and $\mathrm{Co}^{2+}(-\circ-)$ ions by E. densa $\left(20 \mathrm{~g} / \mathrm{dm}{ }^{3}\right.$; f.w. $)$ on dilution of Hoagland medium at $\mathrm{pH} 6.5$ after $8 \mathrm{~d}$ cultivation of fully immersed plants at light/dark cycle $12 \mathrm{~h} / 12 \mathrm{~h}(2000 \mathrm{~lx})$ and $22 \pm 2^{\circ} \mathrm{C}$. For details see Fig. 3.

B. The percentage (ratio of concentration metal form to the total concentration of metal) of cesium in the form of $\mathrm{Cs}^{+}$and cobalt in the forms $\mathrm{Co}^{2+}$ ions, $\mathrm{CoSO}_{4}$ or $\mathrm{CoHPO}_{4}$ in dependence on dilution of Hoagland medium at $\mathrm{pH} 6.5$ and $22^{\circ} \mathrm{C}$ calculated by the speciation program Visual MINTEQ.

As can be seen from Fig. 3A,B and Fig. 4A, $\mathrm{Cs}^{+}$uptake by freshwater submerged plant Egeria densa is strongly dependent on ion concentration in medium. However in the case of cobalt uptake this dependence was less pronounced. Cesium uptake $46 \%$ (32.8 nmol/g; d.w.) in deionized water decreased to $6 \%(6.0 \mathrm{nmol} / \mathrm{g}$; d.w. $)$ in $8.3 \%$ 
$\mathrm{HM}$, where concentration of competing $\mathrm{K}^{+}$and $\mathrm{NH}_{4}{ }^{+}$ions was 0.33 and $0.5 \mathrm{mmol} / \mathrm{dm}^{3}$, respectively. On the contrary, uptake of $\mathrm{Co}^{2+}$ ions increased with concentration of monovalent and bivalent cations in HM, however at highest concentration, i.e. $8 \mathrm{mmol} / \mathrm{dm}^{3} \mathrm{Me}^{+}$ions and $3 \mathrm{mmol} / \mathrm{dm}^{3} \mathrm{Me}^{2+}$ ions in $50 \% \mathrm{HM}$ cobalt uptake slightly decreased. The speciation of cesium and cobalt in individual cultivation media at $\mathrm{pH} 6.5$ and $22^{\circ} \mathrm{C}$ can be seen in Fig. $4 \mathrm{~B}$.

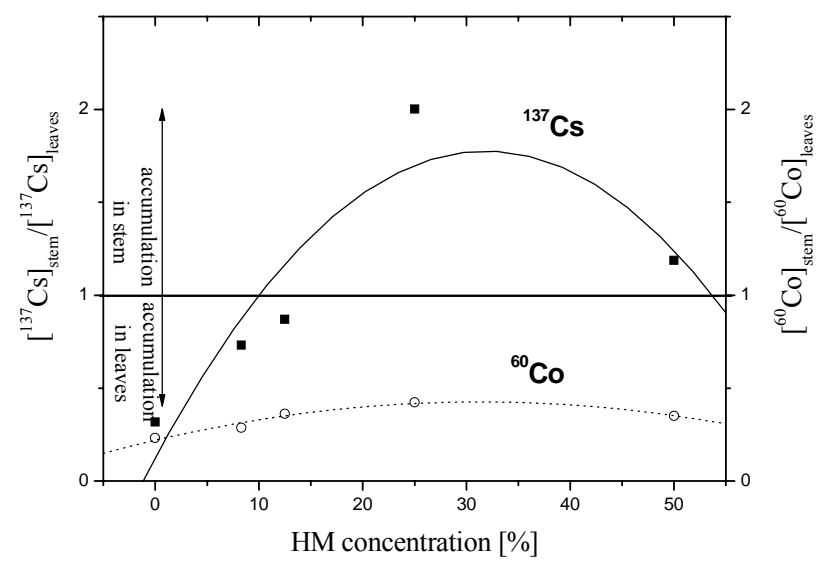

Fig. 5. Influence of dilution of Hoagland medium on ${ }^{137} \mathrm{Cs}\left(-\mathbf{-}_{-}\right)$and ${ }^{60} \mathrm{Co}(-\circ-)$ distribution in stems and leaves of $E$. densa $\left(20 \mathrm{~g} / \mathrm{dm}^{3}\right.$; f.w.) after $8 \mathrm{~d}$ cultivation of fully immersed plants at light/dark cycle $12 \mathrm{~h} / 12 \mathrm{~h}(2000 \mathrm{~lx})$ and $22 \pm 2^{\circ} \mathrm{C}$. Data expressed as the ratio of concentration in stems to the concentration in leaves $(\mathrm{Bq} / \mathrm{g} / \mathrm{Bq} / \mathrm{g}$; d.w.). For details see Fig. 3

Concentration of mineral nutrients had also a significant influence on distribution of ${ }^{137} \mathrm{Cs}$ between stems and leaves of submerged plant E. densa (Fig. 5). In the case of plants cultivation in deionized water containing $0.12 \mu \mathrm{mol} / \mathrm{dm}^{3} \mathrm{CsCl}$ cesium was localized manly in leaves, however with increasing of nutrients concentration in cultivation media cesium was localized for account of stem. On the other hand, cobalt was immobilized mainly in leaves of $E$. densa in whole range of nutrients concentration.

\section{Conclusions}

Cesium and cobalt in contaminated water systems undergo concentration equilibrium in contact with water plants, occurring in nearly all water bodies. Obtained data from short-time laboratory experiments showed, that presence of monovalent and bivalent ions in defined cultivation media significantly influenced the bioaccumulation and distribution of ${ }^{137} \mathrm{Cs}^{+}$and ${ }^{60} \mathrm{Co}^{2+}$ ions in freshwater plants Bacopa monnieri and Egeria densa. These results can serve for understanding of phytoaccumulation of radionuclides from open water ponds and water channels in the vicinity of nuclear power plants and monovalent and bivalent metals from industrial sources of contamination. 


\section{References}

ADAM, CH., GARNIER-LAPLACE, J.: Bioaccumulation of silver-110m, cobalt-60, cesium-137, and manganese-54 by the freshwater algae Scenedesmus obliquus and Cyclotella meneghiana and by suspended matter collected during a summer bloom event. Limnol. Oceanogr., 48, 2003, 2303-2313.

AVERY, S.: Fate of caesium in the environment: distribution between the abiotic and biotic components of aquatic and terrestrial ecosystems. J. Environ. Radioact., 30, 1996, 139-171.

BARÁTOVÁ, Z., SEKÁČOVÁ, J., HORNÍK, M., PIPÍŠKA, M., AUGUSTÍN, J.: Bioaccumulation of ${ }^{137} \mathrm{Cs}$ and ${ }^{60} \mathrm{Co}$ by mustard Sinapis alba L. and celery Apium graveolens L.. Nova Biotechnol., VI-I, 2006, 7-18.

BATTY, L.C., ATKIN, L., MANNING, D.A.C.: Assessment of the ecological potential of mine-water treatment wetlands using a baseline survey of macroinvertebrate communities. Environ. Pollut., 138, 2005, 413-420.

CARON, F., MANKARIOS, G.: Pre-assessment of the speciation of ${ }^{60} \mathrm{Co},{ }^{125} \mathrm{Sb},{ }^{137} \mathrm{Cs}$ and ${ }^{241} \mathrm{Am}$ in a contaminated aquifer. J. Environ. Radioact., 77, 2004, 29-46.

CHEREMISINOFF, N.P.: Handbook of water and wastewater treatment technologies. Butterworth-Heinemann, Woburn, MA, USA, 2002, 631 p.

FIOL, N., SERAROLS, J., POCH, J., MARTÍNEZ, M., MIRALLES, N., VILLAESCUSA, I.: Low Cost Materials for Metal Uptake from Aqueous Solutions. In: Lichtfouse, E., Schwarzbauer, J., Robert, D. (Eds.) Environmental chemistry - Green Chemistry and Pollutants in Ecosystems, Springer-Verlag, Berlin, Heidelberg, 2005, 251-258.

HOAGLAND, D.R.: Optimum nutrient solutions for plants. Science, 52, 1920, 562564.

HORNÍK, M., PIPÍŠKA, M., SEKÁČOVÁ, J., AUGUSTÍN, J.: Determination of long distance transport of $\mathrm{Cs}^{+}, \mathrm{Co}^{2+}$ and $\mathrm{Zn}^{2+}$ ions in vascular plants by autoradiography and gamma-spectrometry. Nova Biotechnol., VII-I, 2007, 33-40.

KELLY, M.S., PINDER III, J.E.: Foliar uptake of ${ }^{137} \mathrm{Cs}$ from the water column by aquatic macrophytes. J. Environ. Radioact., 30, 1996, 271-280.

KERPEN, W.: Bioavailability of the radionuclides cesium-137, cobalt-60, manganese54 and strontium- 85 in various soils as a function of their soil properties. Methods applied and first results. In: Sibley, T.H., Myttenaere, C. (Eds.) Application of distribution coefficients to radiological assessment models. Elsevier, London, $1986,322-335$

LESLEY, B., HOOLEY, D., YOUNGER, P.: Iron and manganese removal in wetland treatment systems: Rates, processes and implications for management. Sci. Tot. Environ., 394, 2008, 1-8.

LESLEY, C.B., YOUNGER, P.L.: The effect of $\mathrm{pH}$ on plant litter decomposition and metal cycling in wetland mesocosms supplied with mine drainage. Chemosphere, 66, 2007, 158-164.

MADRUGA, M.J., CARREIRO, M.C.V.: Experimental study of ${ }^{60} \mathrm{Co}$ behavior in Tejo River sediments. Hydrobiologia, 235/236, 1992, 661-668.

MOULD, R.F.: Chernobyl Record: The Definitive History of the Chernobyl Catastrophe. Institute of Physics Publishing, Bristol, UK, 2000, 402 pp. 
OTTE, M.L., JACOB, D.L.: Constructed wetlands for phytoremediation Rhizofiltration, phytostabilisation and phytoextraction. In: Mackova, M., Dowling, D., Macek, T. (Eds.) Phytoremediation Rhizoremediation, Springer, Dordrecht, The Netherlands, 2006, 57-67.

PEREZ-ESPINOZA, A., MORAL, R., MORENO-CASELLES, J., CORTÉS, A., PEREZ-MURCIA, M.D., GÓMEZ, I.: Co phytoavailability for tomato in amended calcareous soils. Bioresour. Technol., 96, 2005, 649-655.

PINDER III, J.E., HINTON, T.G., WHICKER, F.W.: Foliar uptake of cesium from the water column by aquatic macrophytes. J. Environ. Radioact., 85, 2006, 23-47.

PINDER III, J.E., HINTON, T.G., WHICKER, F.W.: The influence of a whole-lake addition of stable cesium on the remobilization of aged ${ }^{137} \mathrm{Cs}$ in a contaminated reservoir. J. Environ. Radioact., 80, 2005, p. 225-243.

PRASAD, M.N.V.: Aquatic plants for phytotechnology. In: Singh, S.N., Tripathi, R.D. (Eds.) Environmental bioremediation technologies, Springer-Verlag, Berlin, Heidelberg, 2007, 259-274.

SAXÉN, R., ILUS, E.: Transfer and behaviour of ${ }^{137} \mathrm{Cs}$ in two Finnish lakes and their catchments. Sci. Tot. Environ., 394, 2008, 349-360.

SAXÉN, R.: ${ }^{137} \mathrm{Cs}$ in freshwater fish and lake water in Finland after the Chernobyl deposition. Boreal. Environ. Res., 12, 2007, 17-22.

SHAW, G., HEWAMANNA, R., LILLYWHITE, J., BELL, J.N.B.: Radiocesium uptake and translocation in wheat with reference to the transfer factor concept and in competition effects. J. Environ. Radioact., 16, 1992, 167-180.

SMITH, J.T., KUDELSKY, A.V., RYABOV, I.N., HADERINGH, R.H., BULAKOV, A.A.: Application of potassium chloride to a Chernobyl-contaminated lake: modeling the dynamics of radiocaesium in an aquatic ecosystem and decontamination of fish. Sci. Tot. Environ., 305, 2003, 217-227.

STERNBERG, S.P.K.: Phytoremediation with living aquatc plants: Development and modeling of experimental observations. In: Willey, N. (Ed.) Phytoremediation: methods and reviews, Humana Press, Totowa, New Jersey, USA, 2007, 185-203. 